\title{
多視点カメラ映像からの絡み合った身体の姿勢決定
}

\section{Determining Pose of Intertwisting Human Bodies from Multiple Camera Views}

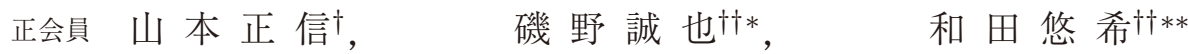

Masanobu Yamamoto ${ }^{\dagger}$, Seiya Isono ${ }^{\dagger * *}$ and Yuki Wada ${ }^{\dagger \dagger * *}$

\begin{abstract}
あらまし 本論文では，レスリングを対象に多視点映像から選手の動作を測定するモーションキャプチャを提案する、レスリング などの格闘技では，選手の身体同士が絡み合い一体化するため，腕や脚がどちらの選手の部位か，人の目で見ても判別には高度な推論 を必要とする。本論文では, 部位の自動認識よりも測定の確実さを優先し, 腕や脚の所属先を教示し，それらの体軸を手動で指定す る．関節位置を手動で指定する従来の方法では，指定する人により位置にブレが生じた，本論文では，四肢の体軸方向から関節位置 を推定する方法を提案する，胴体の姿勢は肩関節と股関節の位置から逆運動学手法を使って推定可能である。このとき，関節位置に は誤差を含むため，関節位置の自己修正を伴う逆運動学手法を提案し胴体の姿勢を求める。一旦モデルを身体像に一致させれば，動 作は身体追跡法により自動的に推定できる。本提案手法は身体追跡の初期設定法と位置付けられる。
\end{abstract}

キーワード：モーションキャプチャ, 多視点カメラ，姿勢推定，レスリング

\section{1. まえがき}

スポーツ選手の技量を高めるためには，その動作の分析 に基づき対策を立てる必要がある。モーションキャプチャ は動作分析のための有力な手段である。これまで, 体操, 野 球，バスケットボール，テニス，ゴルフ，フィギュアスケー 卜等多くの競技を対象にその動作が測定されてきた。しか し，格闘技での使用はあまりない。特に，レスリングや柔 道，相撲など，身体同士が絡み合う競技を対象とした例は 見当たらない.

本論文ではレスリングを対象に選手の動作を測定するモー ションキャプチャを開発する。選手に接触せずに動作を 3 次元的に測定するために，選手の周囲に複数のビデオカメ ラを配置する。選手の多関節モデルを作成しておき，この モデルを選手の身体像に照合させることにより姿勢を得る。

レスリングなどの格闘技では，選手の身体同士が絡み合 い一体化するため, 腕や脚がどちらの選手の部位か, 人の 目で見ても判別には高度な推論を必要とする。本論文では, 腕や脚の主軸を体軸とよび，それらの所属先を教示し，体 軸を手動で指定する，従来の関節位置を手動で指定する方 法では，指定する人により位置にブレが生じる。本論文で

2013 年 11 月 8 日受付, 2014 年 4 月 5 日再受付， 2014 年 5 月 23 日採録 †新潟大学工学部情報工学科

（～950-2181 新潟県新潟市西区五十嵐二の町 8050, TEL 025-262-7428） †十新潟大学大学院自然科学研究科

（干 950-2181 新潟県新潟市西区五十嵐二の町 8050, TEL 025-262-7428

* 現在はインテック (株) に所属

** 現在は $\mathrm{NEC}($ 株) に所属
は，四肢の体軸方向から関節位置をブレなく推定する手法 を提案する．胴体の姿勢は肩関節と股関節の位置から逆運 動学手法を使って推定可能である。このとき，関節位置に は誤差を含むため，関節位置の自己修正を伴う逆運動学手 法を提案し胴体の姿勢を求める。

このモデル照合法は手作業を含むため手間がかかる。し かし，一旦モデルを身体像に一致させれば，動作は身体追 跡法により自動的に推定できる。ただし，追跡に失敗する こともあるので，失敗した時点で再度照合を行う必要もあ る。したがって，本照合法は身体追跡の初期設定法あるい は再設定法と位置付けられる。

次節では，関連研究に対する本論文の位置付けを行い，3 節では身体モデルの定義，4節では，逆運動学手法による 肩関節・股関節からの胴体の姿勢推定法を示す。四肢の関 節位置の指定法は，5節の実験で示す。実験では，先頭フ レームで提案手法により選手の姿勢を与え，フレーム間差 分に基づく身体追跡法 ${ }^{16) 17)}$ により動作を測定する。

\section{2. 関 連 研 究}

レスリングでは身体にマーカーやセンサを取り付けるこ とはできず，ビデオカメラなどのような非接触センサによ り動作を測定する必要がある。正確な 3 次元動作を得るた めには, 多視点ビデオカメラやレンジセンサを使用するこ とになる。

身体の構造は多関節モデルで表すことが多い。センサか らの身体情報にモデルを一致させることにより，身体の姿 勢をモデルの姿勢として得る。このモデル照合には，トッ 
プダウン手法, ボトムアップ手法及び両者の融合手法があ る、トップダウン手法とは, あらかじめ構築された身体モ デルを身体情報に一致させる手法であり, ボトムアップ手 法とは，センサからの身体情報から身体部位を見つけ，そ れらを組合わせることにより身体モデルを構築する方法で ある。実際には，どちらか一方だけが用いられることはな く, 両手法の長所を組合わせた融合手法が用いられている. そこでは，身体情報から抽出された身体部位に身体モデル を照合させている、レンジデータの利用では，Kinect ${ }^{10)}$ 良い例である。

濃淡画像では，背景差分により身体領域を抽出し，姿勢が 立位ならば，身体領域の主軸が同体部の主軸でもある。主 軸上で首の位置を特定し, 胴体部モデルを身体領域に一致 させる.さららに, 上腕・上脚, 下腕・下脚の順に部位の位 置を探索する。この階層的マッチング4) 6)8) は姿勢探索効 率が良い。

屋外など背景が複雑な場合には，腕や胴体のテンプレー トを予め作成しておき，テンプレートマッチングにより部位 の候補を見つける，部位候補の組合わせの中から，トップ ダウン手法により正しい多関節モデルを選択している779).

レスリングは屋内で行われ，撮影環境が制御可能なので 背景差分により身体領域が抽出できる。また，対戦する選 手はシングレットとよばれる赤と青のユニフォームで色分 けされているので, 色情報により胴体の抽出が可能である. さらに, 腕や脚は肌がむき出しになっているので, 肌色情 報で腕や脚が抽出できる.

部位の抽出は可能であるが，選手の身体同士が絡み合っ ているときは, 抽出された腕や脚がどちらの選手の部位か 分からないときもある. 図 1 には 6 台の同期されたビデオ カメラから撮られたレスリングの選手が示されている。青 いシングレットの選手の腕が, 赤いシングレットの選手の 首に巻きついているが，この識別にはかなり高度な推論を 必要とする。手動で入力した四肢の体軸を画像に重ねて示 す。左腕は青系, 右腕はオレンジ系, 左足は緑系, 右脚は 黄色系の線分で色分けしている.

これまで提案されてきた手法は，独立した身体を対象と している。したがって，これまでの手法を使って絡み合っ た身体の姿勢推定は難しいと考えられる。実際, Kinect ${ }^{10)}$ による測定を試みたが，絡み合った二つの身体が一つの未 知の物体となり，二つの身体として分離して識別されるこ とはなかった。

絡み合った身体の自動認識は興味のある問題ではあるが, 本論文では, 測定の確実さを優先し, 腕部や脚部の所属先 を教示し，それらの体軸を手動で指定することにする。

画面上の関節位置を手動で指定し，モデルの部位の両端 を関節位置に当てはめることにより，3次元姿勢を得るこ とができる213)11)。しかし，関節は外見から直接見ることは できないので，その位置は指定する人によりブレを生じる. これに対し，腕や脚は円筒と見なすことができるので，そ

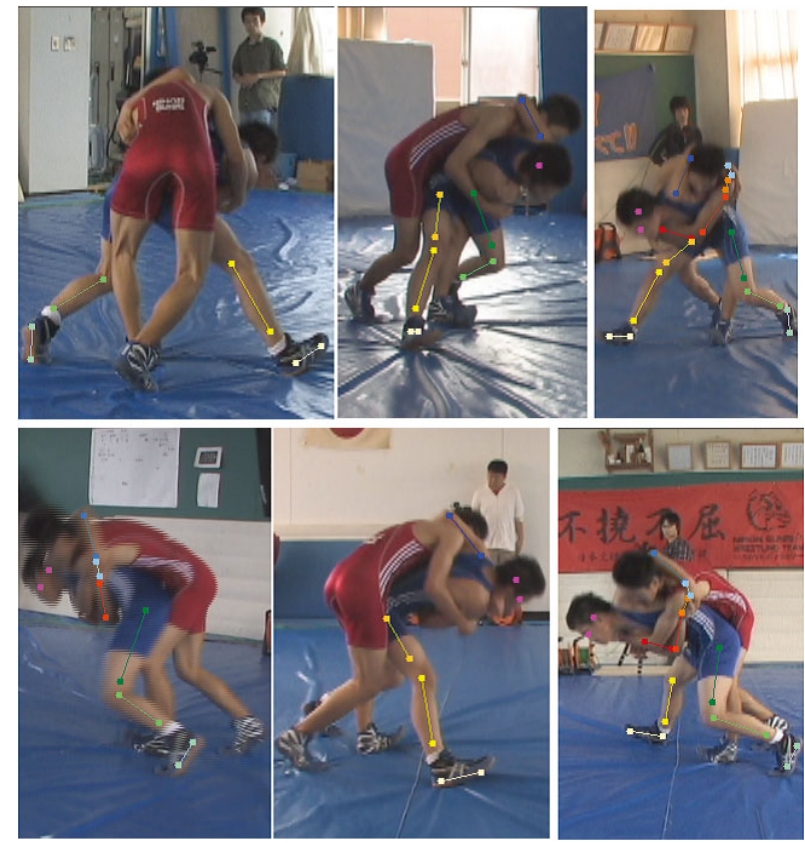

図 1 レスリング選手の多視点カメラ画像と四肢の指定された 体軸

の投影領域の二等分線は比較的正確に部位の主軸を表して いる. 本論文は，この部位の指定された主軸から関節位置 を安定に推定する方法を示す。なお， de Aguiar ら¹ は，身 体の姿勢にモデルを合わせるのではなく，与えられたモデ ルに身体の姿勢を合わせ，その後の追跡により任意の時刻 の姿勢を得ている。しかし，身体同士が絡み合うと追跡に 失敗する可能性が高いことから，本論文ではこの手法は取 らなかった。

再度, 図 1 を見てみよう。青いシングレットの選手はど のカメラからも胴体が充分に見えて㧍らず, 胴体の体軸指定 は難しい。この様な隠れは絡み合った動作では頻繁に起こ る。この問題に対し，全身の姿勢は身体の部分的な姿勢か ら推定することが可能である ${ }^{6) 14}$ ．この手法を使えば，四肢 の体軸から胴体の姿勢を推定することができる．Wei ら ${ }^{14)}$ は，身体姿勢パラメー夕の従属性を利用して，部位の体軸 の指定から全身の姿勢を推定している。この従属性は姿勢 の事例デー夕から統計的に得られるが，レスリングの事例 デー夕はまだないので今回の研究には使えない.

一方，逆運動学手法を使えば，関節の位置から関節間の 部位の姿勢を推定することができる6)。ただし，逆運動学手 法では与えられた位置は正確であることが前提である。し かし，推定された関節位置は誤差を含むこともある．本論 文では, 関節位置の修正を含んだ逆運動学手法を提案し, 肩 関節と股関節の位置から胴体の姿勢を推定する。次節で述 ベるように，本論文では胴体を 2 リンクモデルで表してい るので，与えられた関節の位置情報に対し姿勢の尣長性は ない。この冗長性のなさを利用して，関節位置の誤差を自 己修正し一意な姿勢を得ている。胴体を 3 リンク以上の多 リンク構造で表せば，姿勢に宂長性が出てくる．多数の拘 


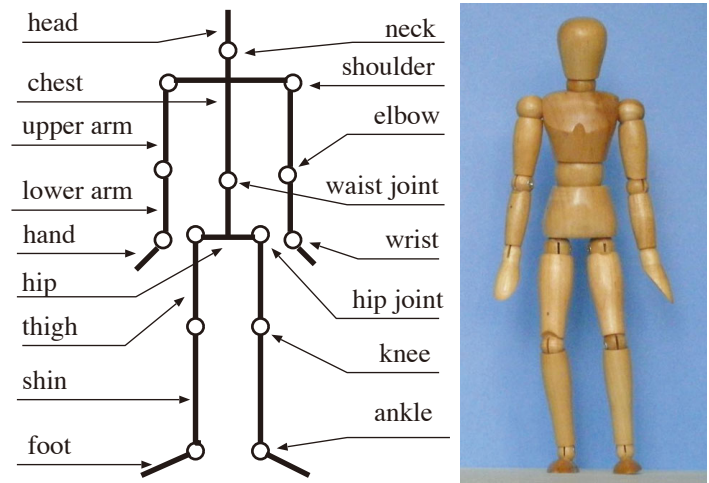

図 2 身体骨格モデル（左）と関節位置および実体モデル（右）

束条件を利用して数值最適化 ${ }^{15)}$ により姿勢を一意に得るこ とも可能である。しかし，図 1 に示されるように胴体は殆 ど見えず，最適化のための拘束条件を加えることが期待で きないので，今回は多リンク構造を採用しなかった。

\section{3. 身体骨格モデル}

身体骨格モデルを, 頭, 胸, 腰, 上腕, 下腕, 手, 上脚, 下 脚, 足などの部位から構成する。ここでは胴体を胸部と腰 部に分け，一つの関節で連結することにする。この関節を 連結点 (waist joint) とよぶ.このモデルを図 2 左に示す. 首, 手首, 肘, 肩, 足首, 膝, 股関節および連結点の位置 が○印で示されている.

対象となる身体各部位の寸法は実測しておく．実測され る寸法は，下腕は手首から肘まで，上腕は肘から肩まで，下 脚は足首から膝まで，上脚は膝から股関節までの各長さで ある。身体が正立しているとき，首の付け根と腰の下端を 結ぶ線分をほほ臍の位置で内分する。内分点から首の付け 根までの長さを胸部の高さ，腰の下端までの長さを腰部の 高さとする。これら腰部, 胸部の高さも実測しておく。

図 2 右には, ターレンスモデル人形 $\mathrm{R}$ (モデル $8 \mathrm{~A}($ 男), ターレンス社) を示す。この市販の人形は，デッサン用に 作られており，身体のおおよその姿勢を表すことができる。 本論文で定義した身体モデルの実体モデルでもあり，提案 手法の評価に使用する.

両肩の中点を首の付け根とし，この点を通り両肩を結ぶ 線分に垂直な面を胸部の正中面と呼ぶ。両脚の付け根の中 点を腰の下端とし，この点を通り両股関節を結ぶ線分に垂 直な面を腰部の正中面と呼ぶ。身体が正立しているとき， 胸と腰の正中面は一致する。

\section{4. 胴体部の姿勢決定}

対象となる身体の両肩関節及び両股関節の 3 次元位置が 与えられているとする。肩関節・股関節を含む四肢の関節 位置の与え方は次節で後述する．実測值に基づく身体骨格 モデルを肩関節・股関節に当てはめ, 胸部と腰部の連結点 を決定する。

両肩の位置が与えられたら，胸部姿勢の自由度は両肩を
結ぶ直線周りの 1 自由度である. 同様に，両脚の股関節の 位置が与えられたなら, 腰部の姿勢の自由度も 1 自由度で ある、胸部と腰部は臍付近で連結しているので，両部位の 姿勢は一意に決まる。胸部と腰部の連結点は，胸部の正中 面と腰部の正中面に載っている。また，この連結点は両肩 の中点及び両股関節の中点からそれぞれ部位の高さほど離 れた位置でもある。この位置は一つの平面に載っている。 この平面を連結面とよぶ。まず，正中面と連結面及びこれ らの面の関係を定式化する。

(a) 正中面

$\mathbf{x}$ を 3 次元座標ベクトルとする。両肩の中点を $\mathbf{p}_{1}$ とし， 両肩を結ぶ直線の単位方向ベクトルを $\mathbf{n}_{1}$ とする。このと き，胸部の正中面は，

$$
\mathbf{n}_{1}^{\top}\left(\mathbf{x}-\mathbf{p}_{1}\right)=0
$$

である。また，両股関節の中点を $\mathbf{p}_{2}$ とし，両股関節を結 ぶ線分の単位方向ベクトルを $\mathbf{n}_{2}$ とする。このとき，腰部 の正中面は

$$
\mathbf{n}_{2}^{\top}\left(\mathbf{x}-\mathbf{p}_{2}\right)=0
$$

である。

(b) 連結面

胸部の高さを $h_{1}$, 腰部の高さを $h_{2}$ とする．胸部と腰部 の連結点は，点 $\mathbf{p}_{1}$ から半径 $h_{1}$ の球面上にあり，かつ点 $\mathbf{p}_{2}$ から半径 $h_{2}$ の球面上にある。両球の方程式を

$$
\begin{aligned}
& \left\|\mathbf{x}-\mathbf{p}_{1}\right\|^{2}=h_{1}^{2} \\
& \left\|\mathbf{x}-\mathbf{p}_{2}\right\|^{2}=h_{2}^{2}
\end{aligned}
$$

とする. 2 つの方程式について両辺の差を求めれば，平面 の方程式

$$
\left(\mathbf{p}_{2}-\mathbf{p}_{1}\right)^{\top} \mathbf{x}=\frac{1}{2}\left(\left\|\mathbf{p}_{2}\right\|^{2}-\left\|\mathbf{p}_{1}\right\|^{2}+h_{1}^{2}-h_{2}^{2}\right)
$$

が得られる。もし両球が交われば，この平面は両球の交線 を含んでいるので，連結点もこの平面上に存在する。この 平面を連結面と呼ぶ.

2 つの中点を結ぶ直線が連結点と交わる位置 $\mathbf{p}_{0}$ を求めて おく．交点 $\mathbf{p}_{0}$ は任意定数 $\lambda$ を使って，

$$
\mathbf{p}_{0}=\mathbf{p}_{1}+\lambda\left(\mathbf{p}_{2}-\mathbf{p}_{1}\right)
$$

と表せる。 $\mathbf{p}_{0}$ を連結面 (5) の $\mathrm{x}$ に代入すれば，

$$
\lambda=\frac{1}{2}\left(1+\frac{h_{1}^{2}-h_{2}^{2}}{d^{2}}\right)
$$

が得られる.ここで, $d=\left\|\mathbf{p}_{2}-\mathbf{p}_{1}\right\|$ とする。 したがって，

$$
\mathbf{p}_{0}=\frac{\left(d^{2}-h_{1}^{2}+h_{2}^{2}\right) \mathbf{p}_{1}+\left(d^{2}+h_{1}^{2}-h_{2}^{2}\right) \mathbf{p}_{2}}{2 d^{2}}
$$

となる。すなわち， $\mathbf{p}_{0}$ は $\mathrm{p}_{1}$ と $\mathrm{p}_{2}$ を端点とする線分を $\left(d^{2}+h_{1}^{2}-h_{2}^{2}\right):\left(d^{2}-h_{1}^{2}+h_{2}^{2}\right)$ に内分する点である.

中点位置 $\mathbf{p}_{1}, \mathbf{p}_{2}$ や連結点 $\mathbf{p}$ および正中面の向き $\mathbf{n}_{1}, \mathbf{n}_{2}$ 

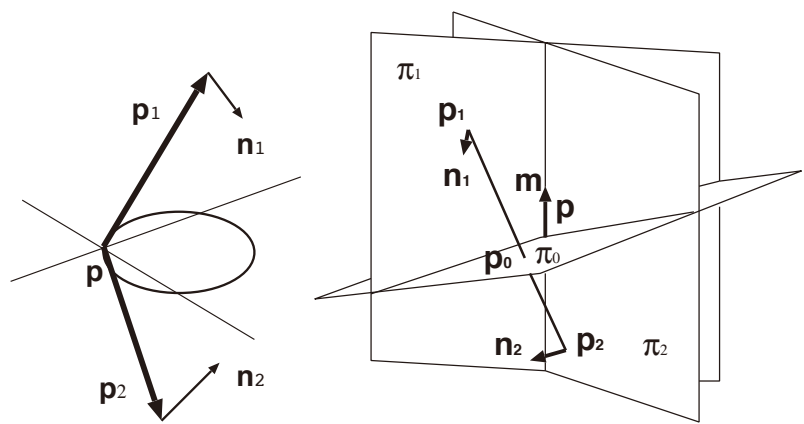

図 3 腰部と胸部からなる胴体の 2 リンクモデル (左), 2 つの 正中面と連結面（右）

を図 3 左に示しておく．円は中点を中心とし半径を部位の 高さとする 2 つの球の交線であり, 連結面上に描かれる. 連結点を通る 2 本の直線は，2つの正中面と連結面との交 線である。

(c) 正中面と連結面の関係

胸部と腰部の連結点は二つの正中面上にある。そのため には，2つの正中面が交わるか一致していることが必要で ある． 2 つの正中面の法線がなす角度を $\theta$ とすれば，その 正弦は,

$$
|\sin \theta|=\frac{\left\|\mathbf{n}_{1} \times \mathbf{n}_{2}\right\|}{\left\|\mathbf{n}_{1}\right\|\left\|\mathbf{n}_{2}\right\|}
$$

で与えられる. $\theta=0$ のとき， 2 つ面は平行であり，そう でなければ交わる。

2 つの正中面が交わり，その交線が連結面と交わるなら ば，その交点が連結点となる．2つの正中面の交線の方向 ベクトルを $\mathbf{m}$, この交線と連結面の法線ベクトル $\mathbf{p}_{1}-\mathbf{p}_{2}$ とのなす角度を $\phi$ とすれば，この余弦は，

$$
\cos \phi=\frac{\mathbf{m}^{\top}\left(\mathbf{p}_{1}-\mathbf{p}_{2}\right)}{\|\mathbf{m}\|\left\|\mathbf{p}_{1}-\mathbf{p}_{2}\right\|}
$$

で与えられる。ただし， $\mathbf{m}=\mathbf{n}_{1} \times \mathbf{n}_{2}$. このとき，式 (10)

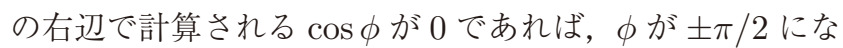
るので，交線は連結面と平行になり，そうでなければ交わ る. 2 つの正中面と連結面の関係から身体の姿勢を次の 3 つに分類する.

念転姿勢 2 つの正中面は交わり，その交線が連結面に交 わる。

横斜姿勢 2 つの正中面は交わるが，その交線が連結面に 平行である.

直立姿勢 2 つの正中面が平行である。

各姿勢の詳細は次節以降で考察する.

\section{1 捻転姿勢}

二つの正中面が交わり，その交線に連結面が交わるなら ば， $\mathbf{x}$ に関する線形方程式 (1),(2),(5) の連立方程式

$$
\left\{\begin{aligned}
\mathbf{n}_{1}^{\top} \mathbf{x} & =\mathbf{n}_{1}^{\top} \mathbf{p}_{1} \\
\mathbf{n}_{2}^{\top} \mathbf{x} & =\mathbf{n}_{2}^{\top} \mathbf{p}_{2} \\
\left(\mathbf{p}_{2}-\mathbf{p}_{2}\right)^{\top} \mathbf{x} & =\frac{1}{2}\left(\left\|\mathbf{p}_{2}\right\|-\left\|\mathbf{p}_{1}\right\|+h_{1}^{2}-h_{2}^{2}\right)
\end{aligned}\right.
$$

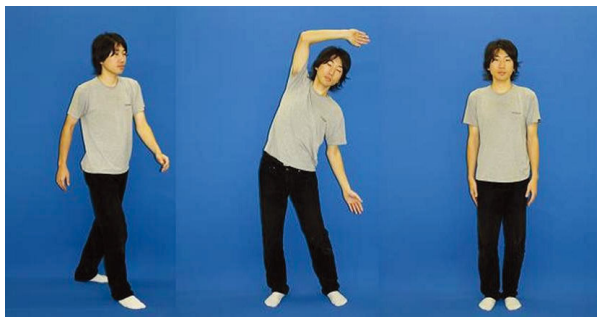

図 4 捻転 (左), 横斜 (中), 直立 (右) 姿勢

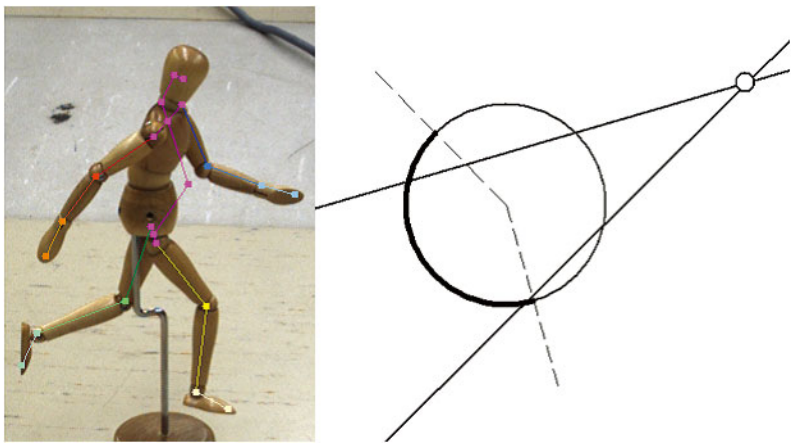

図 5 （左）人形の推定された骨格. 連結点は身体の前方に飛 び出している. (右) 連結面上の円（2つの球体の交線, 直線（正中面との交線），2 直線の交点（連結点）

は独立となり，連結点はこの連立方程式の唯一の解として 得られる。得られた連結点を $\mathrm{p}$ とする。図 3 右に, 連結点 $\mathbf{p}$, 中点 $\mathbf{p}_{1}$ と $\mathbf{p}_{2}$ 及び， $\mathbf{p}_{0}, 2$ つの正中面 $\pi_{1}$ と $\pi_{2}$ 及び連 結面 $\pi_{0}$ などの関係を示す．身体的には，3つの平面が交わ るのは体を捻転させているときなので，この姿勢を捻転姿 勢と呼ぶことにする。図 4 左に捻転姿勢の例を示す.

（1）推定誤りの例

図 5 左に連結点の推定例を示す。この連結点は前方へひ どく飛び出している。なぜこのような誤った連結点が得ら れたのであろうか.

連結点は線形連立方程式 (11) から得られる。このとき, 中点位置 $\mathbf{p}_{1}, \mathbf{p}_{2}$ や正中面の向き $\mathbf{n}_{1}, \mathbf{n}_{2}$ などの測定量に誤 差が含まれているなら誤った連結点が得られる。

連立方程式 (11) は連結点を得るための必要条件であって 充分条件を満たしてはいない。連結点は両肩中点 $\mathbf{p}_{1}$ との 距離が胸部の高さ $h_{1}$ に等しく, 両股間節の中点 $\mathbf{p}_{2}$ との距 離が腰部の高さ $h_{2}$ に等しくなくてはならないが, 連立方程 式にはこの条件が含まれていない. したがって，誤って得 られた連結点はそれぞれの中点との距離が，部位の定めら れた高さに等しくない可能性がある。もし，等しくなけれ ば，このずれをなくするように測定量が自己修正でき，改 めて連結点を求める。ただし，測定量が誤差を含んでいて も，ずれを発生させなければ，正しい連結点が得られてい るわけであるので誤差を修正する必要がない.

\section{（2）修正量の選択}

測定量は中点の位置と正中面の向きであり，それぞれ 3 (11) つと 2 つの自由度を持っている。これらの測定量に誤差が 含まれているとき, 発生したずれから誤差を修正し, 正し 
い連結点を得ることのできる自由度を選択する。

中点位置と正中面の向きに正しい測定值が与えられてい るとする。便宜上，連結点を原点に置けば，図 3 左のよう に中点の位置ベクトル $\mathrm{p}_{1}$ と $\mathrm{p}_{2}$ は, それぞれ胸部と腰部の 体軸を表す軸べクトルとなる。このとき， $\mathbf{n}_{1}$ と $\mathbf{n}_{2}$ は，そ れぞれに体軸 $\mathbf{p}_{1}$ と $\mathbf{p}_{2}$ に直交し， $\mathbf{p}_{1}$ と $\mathbf{p}_{2}$ の長さは, $h_{1}$ と $h_{2}$ に等しい. したがって, 連立方程式 (11) の右辺の值は 0 であり, 得られた連結点は原点となる. 中点位置と正中 面の向きに誤差が含まれると, 連結点は原点近傍にずれる. それぞれの自由度に誤差を与えたとき, 得られた連結点と 中点との距離が伸縮すればその自由度は修正可能となる。

まず，中点位置は正しく与えられているが，正中面の向き に誤差が含まれているとしょう。向きの誤差を，中点位置 ベクトルを軸とする回転と, 正中面の向きと中点位置べク トルに直交する方向を軸とする回転に分解する。このうち 前者は修正する必要がない. なぜなら, 式 (11) の右辺はゼ ロベクトルのままであり正しい連結点位置が得られるから である。一方, 後者に対しては, 右辺の内積は 0 とはなら ず，連結点が原点からずれ，中点との距離が伸縮する。そ のため，向きの誤差は修正可能である.

次に, 正中面の向きは正しく与えられ, 中点位置ベクトル に常に直交しているとするが，中点位置べクトルの向きに 誤差が含まれているとしよう。このとき，連立方程式 (11) の右辺は常に 0 であり, 中点位置に誤差が含まれているに も関わらず正しい連結点が得られる。この誤差は修正する 必要がない。

一方，中点位置ベクトルの伸縮による誤差は，連立方程 式 (11) の 3 番目の方程式の右辺が 0 とはならず, 得られ る連結点は原点からずれてしまう。このずれにより，得ら れた連結点と中点との距離が伸縮すれば誤差を修正できる. しかし，この修正は上手く行かない．実際，連結点との距 離が部位の高さになるように中点位置べクトルを伸縮させ ると, この誤って得られた連結点が “正しい”連結点として 固定されてしまうからである。

結論として, 中点の位置は正しく与えられているとし, 正 中面の向きと中点位置べクトルに直交する方向を軸とする 正中面の回転のみを修正することができる．残りの自由度 の誤差は修正できないか, 修正する必要がないかのいずれ かである。

（3）逐次修正法

連立方程式 (11) から得られた連結点を $\mathrm{x}$ とする。正中 面の向きを修正するための回転軸を，胸部正中面について は $\mathbf{v}_{1}$, 腰部正中面については $\mathbf{v}_{2}$ とすれば,

$$
\left\{\begin{array}{l}
\mathbf{v}_{1}=\frac{\mathbf{n}_{1} \times\left(\mathbf{x}-\mathbf{p}_{1}\right)}{\left\|\mathbf{n}_{1} \times\left(\mathbf{x}-\mathbf{p}_{1}\right)\right\|} \\
\mathbf{v}_{2}=\frac{\mathbf{n}_{2} \times\left(\mathbf{x}-\mathbf{p}_{2}\right)}{\left\|\mathbf{n}_{2} \times\left(\mathbf{x}-\mathbf{p}_{2}\right)\right\|}
\end{array}\right.
$$

である.胸部と腰部の正中面の回転角をそれぞれ $\theta_{1}, \theta_{2}$ と し，この回転角の大きさが小さいとすれば，修正後の正中 面の向きはロドリゲスの公式を使って

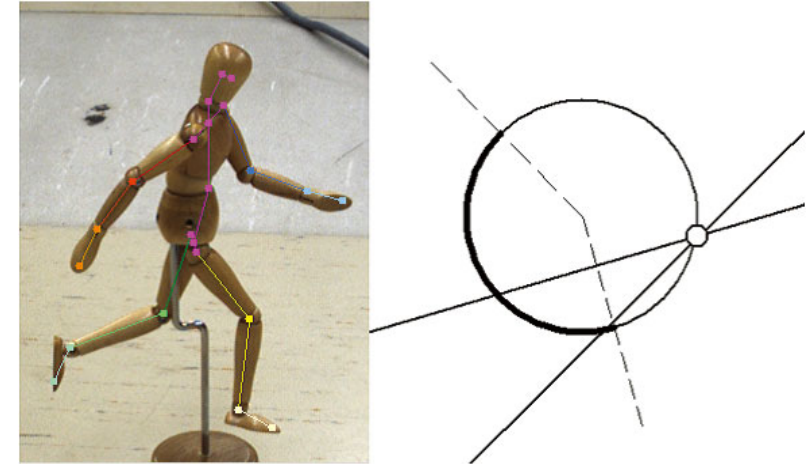

図 6 逐次修正法による連結点

$$
\left\{\begin{array}{l}
\mathbf{n}_{1}\left(\theta_{1}\right)=\mathbf{n}_{1}+\theta_{1} \mathbf{v}_{1} \times \mathbf{n}_{1} \\
\mathbf{n}_{2}\left(\theta_{2}\right)=\mathbf{n}_{2}+\theta_{2} \mathbf{v}_{2} \times \mathbf{n}_{2}
\end{array}\right.
$$

と与えられる。このとき, 連立方程式 (11) の解 $\mathbf{x}$ は $\theta_{1}, \theta_{2}$ の関数となる。したがって, 連結点から中点への距離と部 位の高さとの差は,

$$
\left\{\begin{array}{l}
e_{1}\left(\theta_{1}, \theta_{2}\right)=\left\|\mathbf{x}\left(\theta_{1}, \theta_{2}\right)-\mathbf{p}_{1}\right\|^{2}-h_{1}^{2} \\
e_{2}\left(\theta_{1}, \theta_{2}\right)=\left\|\mathbf{x}\left(\theta_{1}, \theta_{2}\right)-\mathbf{p}_{2}\right\|^{2}-h_{2}^{2}
\end{array}\right.
$$

と表される．上式の右辺を 0 とおき， $\theta_{1}$ と $\theta_{2}$ に関する連立 方程式を解けば修正のための回転が得られる。ただ，こ の連立方程式は非線形であるため線形化し繰り返し演算に より, 右辺が 0 となるような方程式 (11) の解を連結点と する。

この方法で得た骨格線を図 6 左に示す。連結点は相変わ らず前方へ出ており修正されていないことが分かる。なぜ であろうか.この問題を次項で考察する。

\section{（4）局所解への収束問題}

連立方程式 (11) の解は, 連結面と 2 つの正中面との交線 が交わる点である。この交点が正しい連結点であるために は，中点を中心とし半径を部位の高さとした 2 つ球が交 わる円周上に存在しなくてはならない.

図 5 右には連結面上の円周が示されている。2つの直線 は正中面との交線であり，白抜き点で表された交点が連結 点である。この連結点は円周外であるため, 中点との距離 は部位の高さより長くなる。図 6 右には逐次近似法により 修正された連結点が描かれている，円周上にあるが，身体 の前方方向（図の右上方向）に偏っており正しい連結点で はない.

図 7 には図 6 よりは，胸部が腰部に対し大きく据れた姿 勢の連結点が示されている。これは正しく得られた連結点 である。図 6 と図 7 の違いは, 連結面と正中面が交わる 2 つの交線が連結面上で交わる角度が，図 6 では浅く図 7 で は深いことである．正中面の修正方向は連結面上では, それ ぞれの交線と直交する方向となる。したがって，2つの交 線が浅く交わるときは，正中面の向きの僅かな誤差でも交 点の位置は大きく移動する。図 6 では正しい連結点の位置 は身体の後方であるのに，誤差により前方に移ったと考え 


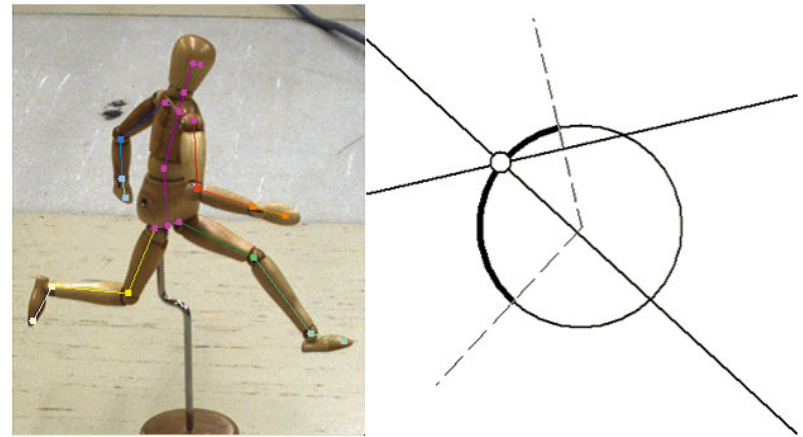

図 7 強度の年点姿勢により正しく得られた連結点

られる。したがって，逐次計算の初期位置を適切に与える 必要がある。

（5）連結点の初期位置推定

正中面の向きの誤差で連結点の位置が大きく移動しても， 正しい位置を得るためには，連結点の初期位置をあらかじ め推定しておく必要がある。

一般に，人の姿勢は前屈みがちであり，連結点は身体の 後方に位置する。身体が前屈みか反り返りかを決定するた めに手首の位置に着目した。両手首が身体の後方にあると き反り返りとし，それ以外は前屈みとした。

ただし，両手首が身体前方にあっても反り返りの姿勢を 作ることができるし，身体後方にあっても前屈みの姿勢を 作ることができる。しかし，それらは強制力を伴う無理な 姿勢であると考えられ，ここでは手と胴体がバランスをとっ ている自然な姿勢を対象とする。

身体の前方と後方を分けるために, 両肩及び 2 つの中点 を含む平面, $\mathbf{m}_{1}^{\top}\left(\mathbf{x}-\mathbf{p}_{1}\right)=0$ と両股間節及び 2 つの中 点を含む平面 $\mathbf{m}_{2}^{\top}\left(\mathbf{x}-\mathbf{p}_{2}\right)=0$ を境界面とした。ただし， $\left.\mathbf{m}_{1}=\left(\mathbf{p}_{2}-\mathbf{p}_{1}\right) \times \mathbf{n}_{1}\right) /\left\|\left(\mathbf{p}_{2}-\mathbf{p}_{1}\right) \times \mathbf{n}_{1}\right\|$ は胸部の前方方 向, $\left.\mathbf{m}_{2}=\left(\mathbf{p}_{1}-\mathbf{p}_{2}\right) \times \mathbf{n}_{1}\right) /\left\|\left(\mathbf{p}_{1}-\mathbf{p}_{2}\right) \times \mathbf{n}_{2}\right\|$ は腰部の前 方方向とする.

両手首が 2 つの境界面より後方にあるとき，反り返りと した，すなわち，左手首位置 $\mathbf{p}_{l}$ と右手首位置 $\mathbf{p}_{r}$ が，

$$
\begin{array}{r}
\left(\mathbf{m}_{1}^{\top}\left(\mathbf{p}_{l}-\mathbf{p}_{1}\right) \leqq w\right) \wedge\left(\mathbf{m}_{2}^{\top}\left(\mathbf{p}_{l}-\mathbf{p}_{2}\right) \leqq w\right) \wedge \\
\left(\mathbf{m}_{1}^{\top}\left(\mathbf{p}_{r}-\mathbf{p}_{1}\right) \leqq w\right) \wedge\left(\mathbf{m}_{2}^{\top}\left(\mathbf{p}_{r}-\mathbf{p}_{2}\right) \leqq w\right)
\end{array}
$$

が真のとき反り返りとし，連結点は身体の前方にあるとし た。この条件が偽のとき前屈みとし，連結点は身体の後方 にあるとした。なお，wはマージンである。

この境界面は胸部や腰部の前後を分ける冠状面 (coronal plane) に似ているが異なる．胸部冠状面なら両肩と連結点 を含む平面，腰部冠状面なら両股間節と連結点を含む平面 とするところであるが，連結点が正確に得られていないの で，連結点の代わりに中点を使用している。そのため，手 首位置が境界面よりも若干後方にずれていても前屈みの条 件を満たすとしたそそのためのマージンが $w(<0)$ である.

このように，胴体に対する手首の相対位置から連結点の 存在領域を予想しておく. 正中面の向きを式 (13) で修正さ
せ，方程式 (11) から得た連結点 $\mathbf{x}\left(\theta_{1}, \theta_{2}\right)$ のうち，身体前 方あるいは後方の予想領域に含まれる中で最適な位置を求 める．最適性の評価に正中面の向きの尤度を利用する，正 中面の向きは $\theta_{1}, \theta_{2}$ を変数として式 $(13)$ で変化させる.こ のとき，正中面の向きの尤度 $L_{1}\left(\theta_{1}\right), L_{2}\left(\theta_{2}\right)$ を，

$$
\begin{aligned}
& L_{1}\left(\theta_{1}\right) \simeq \exp \left(-\theta_{1}^{2}-\left(\left\|\mathbf{p}-\mathbf{p}_{1}\right\|-h_{1}\right)^{2}\right) \\
& L_{2}\left(\theta_{2}\right) \simeq \exp \left(-\theta_{2}^{2}-\left(\left\|\mathbf{p}-\mathbf{p}_{2}\right\|-h_{2}\right)^{2}\right)
\end{aligned}
$$

とする. 評価関数は 2 つの尤度 $L_{1}\left(\theta_{1}\right)$ と $L_{2}\left(\theta_{2}\right)$ の積とす る. 方程式 (11) から得た連結点 $\mathrm{x}$ が予想された領域に含 まれるという条件の下で，評価関数值を最大とする連結点 を求める.

すなわち，連結点が身体の後方に位置する場合には，連 結点の予想領域 $R$ を

$$
\begin{array}{r}
R=\left\{\mathbf{x}\left(\theta_{1}, \theta_{2}\right) ;\left(\mathbf{m}_{1}^{\top}\left(\mathbf{x}\left(\theta_{1}, \theta_{2}\right)-\mathbf{p}_{1}\right) \leqq w\right)\right. \\
\left.\wedge\left(\mathbf{m}_{2}^{\top}\left(\mathbf{x}\left(\theta_{1}, \theta_{2}\right)-\mathbf{p}_{2}\right) \leqq w\right)\right\}
\end{array}
$$

とし，身体の前方に位置する場合には，

$$
\begin{array}{r}
R=\left\{\mathbf{x}\left(\theta_{1}, \theta_{2}\right) ;\left(\mathbf{m}_{1}^{\top}\left(\mathbf{x}\left(\theta_{1}, \theta_{2}\right)-\mathbf{p}_{1}\right)>w\right)\right. \\
\left.\wedge\left(\mathbf{m}_{2}^{\top}\left(\mathbf{x}\left(\theta_{1}, \theta_{2}\right)-\mathbf{p}_{2}\right)>w\right)\right\}
\end{array}
$$

とする。この領域は前屈みの判定条件よりも狭いことに 注意.

この条件下で，最適化

$$
\mathbf{x}\left(\theta_{1}, \theta_{2}\right)=\arg \max _{\mathbf{x}\left(\theta_{1}, \theta_{2}\right) \in R} P_{1}\left(\theta_{1}\right) P_{2}\left(\theta_{2}\right)
$$

により初期位置が得られる。正中面の向きの修正量は小さ いとし，限られた範囲 $-\alpha \leqq \theta_{1}, \theta_{2} \leqq \alpha,(\alpha>0)$ 内で最 適化を行う。この最適化は粗い探索で充分である。例えば， $\alpha=10^{\circ}$ とし， $1^{\circ}$ のキザミで $\theta_{1}$ と $\theta_{2}$ を選べば，式 (13) で向きを修正し，式 (11) より $21 \times 21$ 通りの連結点候補が 得られる。このうち連結点の予想領域内の候補を残し，そ れらの中から最適な候補を初期位置とする.

得られた初期位置から，逐次修正法により正しい連結点 に収束させる。最終的に得られた連結点を含む骨格線を図 8 左に示す。同図右では連結点を連結面上に表示する。な お，2本の破線で挟まれ太線で描かれた円弧を含む扇形の 領域が連結点の予想領域である。ここでは身体の後方であ り，得られた連結点はこの領域内に位置している。さらに， 図 9 では，得られた骨格線を他のカメラからの画像に重ね て示す。

さらに，反り返りの場合の推定結果を図 10 に示してお く，両手を後ろで組んだ姿勢で，身体の前方に連結点が位 置している。

\section{2 横斜姿勢}

胸部と腰部の正中面が交わっているが，その交線が連結 面に平行であるとする。このときの 3 面の関係を図 11 左 に示す。このように，2つの正中面の交線が連結面に平行 


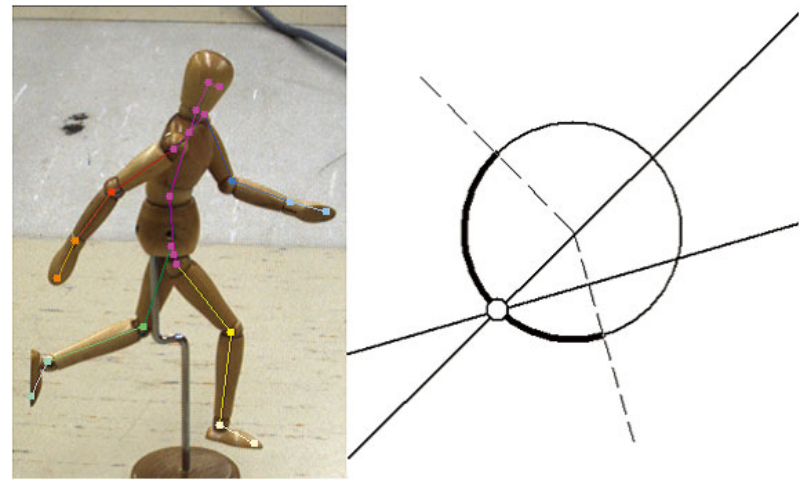

図 8 適切な初期位置からの逐次修正により得られた正しい連 結点

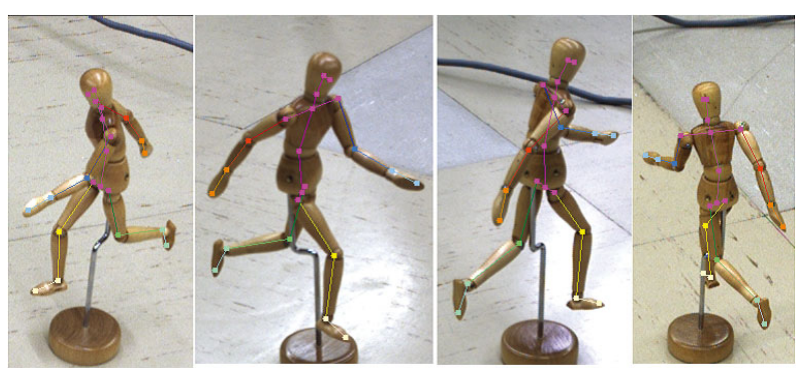

図 94 つの視点から見た図 8 の推定された骨格
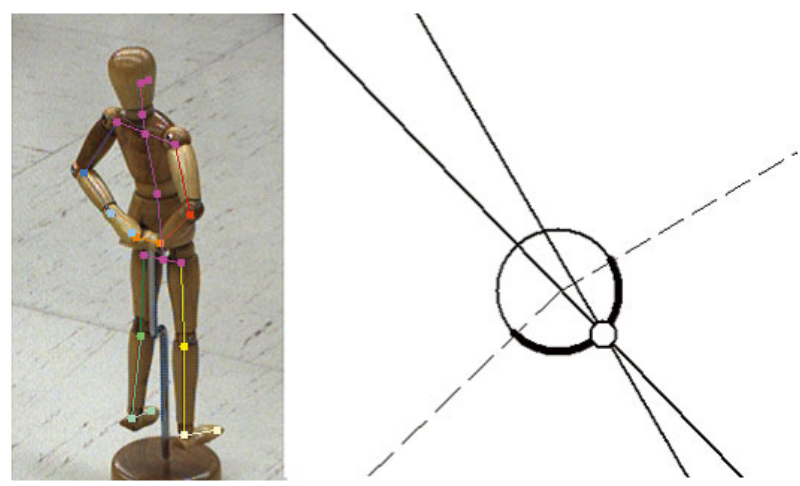

図 10 反り返った姿勢をとっている人形の推定された骨格
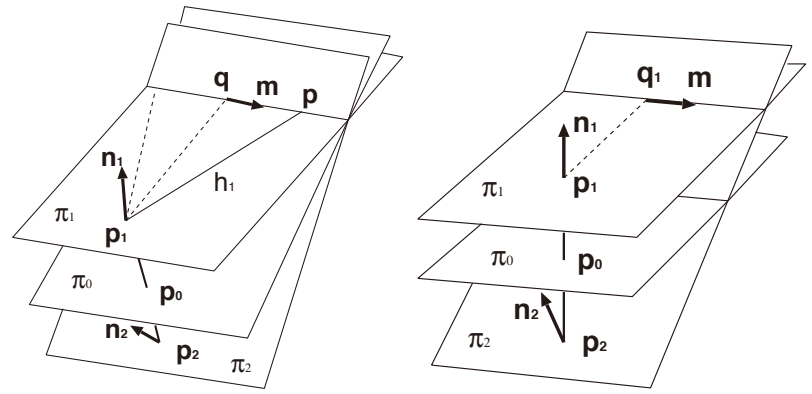

図 11 左：2つの正中面と連結面が 1 直線を共有する. 右 $: 2$ つの正中面の交線が連結面に平行

となるのは，主に体が真横に傾いている時なので，この姿 勢を横斜姿勢と呼ぶことにする。図 4 中に横斜姿勢の例を 示す.

図 11 左では連結点が 3 面の共有線上に存在するが，右 図のように，測定誤差により連結面が正中面の交線を含ま ないこともある。この場合は連結点が存在しない。そこで,

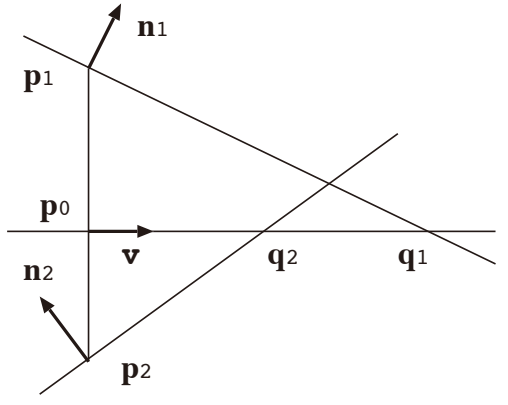

図 12 法線ベクトル $\mathbf{p}_{1}-\mathbf{p}_{2}, \mathbf{n}_{1}, \mathbf{n}_{2}$ は $\mathbf{m}$ を法線とする平 面上に存在する。

胸部および腰部正中面を修正し，図 11 左の状態にする。

まず，2つの正中面の交線の方向ベクトル $\mathbf{m}$ は，2つの 正中面上のベクトルであるので, $\mathbf{m}=\mathbf{n}_{1} \times \mathbf{n}_{2} /\left\|\mathbf{n}_{1} \times \mathbf{n}_{2}\right\|$ で与えられる。また，連結面に平行でもあるので，連結面の 法線 $\mathbf{p}_{1}-\mathbf{p}_{2}$ に直交する． $\mathbf{n}_{1}, \mathbf{n}_{2}$ の始点をそれぞれ $\mathbf{p}_{1}, \mathbf{p}_{2}$ とすれば， 3 つの法線ベクトル $\mathbf{p}_{1}-\mathbf{p}_{2}, \mathbf{n}_{1}, \mathbf{n}_{2}$ は $\mathbf{m}$ を法 線とする平面上に存在する。この平面上の各点の配置を図 12 に示す。この図で連結面上の単位ベクトルを $\mathrm{v}$ とする. $\mathbf{v}=\mathbf{m} \times\left(\mathbf{p}_{1}-\mathbf{p}_{0}\right) /\left\|\mathbf{m} \times\left(\mathbf{p}_{1}-\mathbf{p}_{0}\right)\right\|$ である.

このとき，胸部正中面および腰部正中面と連結面の交点 を $\mathbf{q}_{1}, \mathbf{q}_{2}$ とすれば，それぞれ，

$$
\begin{aligned}
& \mathbf{q}_{1}=\mathbf{p}_{0}+\frac{\mathbf{n}_{1}^{\top}\left(\mathbf{p}_{1}-\mathbf{p}_{0}\right)}{\mathbf{n}_{1}^{\top} \mathbf{v}} \mathbf{v} \\
& \mathbf{q}_{2}=\mathbf{p}_{0}+\frac{\mathbf{n}_{2}^{\top}\left(\mathbf{p}_{2}-\mathbf{p}_{0}\right)}{\mathbf{n}_{2}^{\top} \mathbf{v}} \mathbf{v}
\end{aligned}
$$

で与えられる。この 2 つの交点が一致するように，胸部 正中面を $\mathbf{p}_{1}$ を中心に $\mathbf{m}$ の向きを回転軸として $\theta_{1}$ 回転さ せ正中面の向きを修正する。回転させた正中面の向きは, $\mathbf{n}_{1}\left(\theta_{1}\right)=T_{1}\left(\theta_{1}\right) \mathbf{n}_{1}$ とする.ここで, $T_{1}\left(\theta_{1}\right)$ は回転行列で ある. 同様に腰部正中面も, $\mathbf{p}_{2}$ を中に $\theta_{2}$ 回転させ向きを 修正する. 修正された向きを, $\mathbf{n}_{2}\left(\theta_{2}\right)=T_{2}\left(\theta_{2}\right) \mathbf{n}_{2}$ とする.

交点 $\mathbf{q}_{1}, \mathbf{q}_{2}$ が一致するためには，

$$
\frac{\mathbf{n}_{1}^{\top}\left(\theta_{1}\right)\left(\mathbf{p}_{1}-\mathbf{p}_{0}\right)}{\mathbf{n}_{1}^{\top}\left(\theta_{1}\right) \mathbf{v}}=\frac{\mathbf{n}_{2}^{\top}\left(\theta_{2}\right)\left(\mathbf{p}_{2}-\mathbf{p}_{0}\right)}{\mathbf{n}_{2}^{\top}\left(\theta_{2}\right) \mathbf{v}}
$$

でなければならない.なお， $\theta_{1}$ と $\theta_{2}$ の大きさが小さいと き, 式 $(23)$ は, $\theta_{1}$ と $\theta_{2}$ に関する 1 次方程式で近似できる. この条件下で, 最適化

$$
\theta_{1}, \theta_{2}=\arg \max _{\theta_{1}, \theta_{2}} L_{1}\left(\theta_{1}\right) L_{2}\left(\theta_{2}\right)
$$

により修正量が得られ，一致した 2 つの交点をあらためて $\mathbf{q}$ とおく.

2 つの正中面と連結面が図 11 左のように 1 直線で交わっ ているとき, 連結点を決定する. 交線と点 $\mathrm{p}_{1}$ との最短距 離は, $\left\|\mathbf{p}_{1}-\mathbf{q}\right\|$ である.このとき, 点 $\mathbf{p}_{1}$ からの距離が $h_{1}$ の交線上の点が連結点である。この交線上の連結点はもう 1 点ある。すなわち，連結点は，

$$
\mathbf{p}=\mathbf{q} \pm \sqrt{h_{1}^{2}-\left\|\mathbf{p}_{1}-\mathbf{q}\right\|^{2}} \mathbf{m}
$$




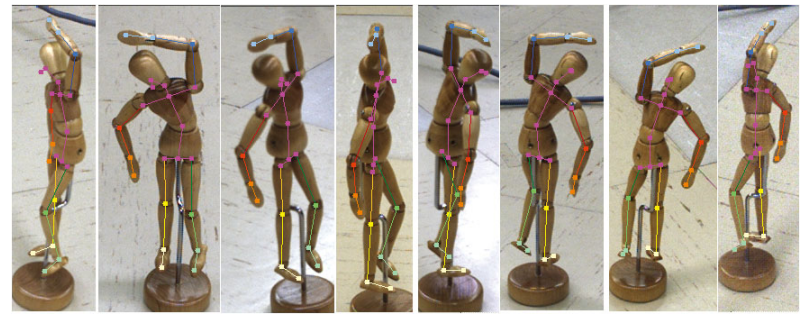

図 13 横斜姿勢の推定結果
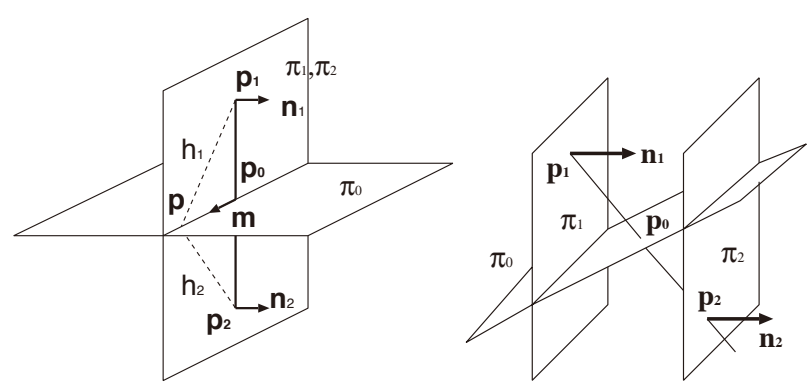

図 14 左：一致した 2 つの正中面, 右：平行な 2 つの正中面

で与えられる。この 2 つの連結点候補のうち, 手首の位置 から推測される連結点の予想領域に含まれる方を連結点と する。

図 13 では，横斜姿勢として推定された骨格線を，8つの カメラ画像上に重ねて示す。

\section{3 直立姿勢}

2 つの正中面が平行である場合は，主に直立していると きなので，この姿勢を直立姿勢と呼ぶことにする。図 4 右 に直立姿勢の例を示す。他に，前屈姿勢や後屈姿勢も正中 面が平行であれば直立姿勢に含める.

一致した 2 つの正中面と $\mathbf{p}_{1}, \mathbf{p}_{2}, \mathbf{n}_{1}, \mathbf{n}_{2}$ との関係を図 14 左に示す。同図右のように, 測定誤差により 2 つの正中 面が一致せず互いに平行な場合には，3つの面が交わる点， すなわち連結点が存在しない.

そこで，2つの正中面が一致するように正中面の向きを 修正したうえで連結点を求める。胸部正中面は， $\mathrm{p}_{1}$ を中心 に $\mathrm{p}_{2}$ を含むように回転させ修正する。修正後の正中面の 向きは, $\left(\left(\mathbf{p}_{2}-\mathbf{p}_{1}\right) \times \mathbf{n}_{1}\right) \times\left(\mathbf{p}_{2}-\mathbf{p}_{1}\right)$ となる.この向き に等しくなるように $\mathbf{n}_{1}$ を修正する，腰部正中面の向き $\mathbf{n}_{2}$ も同様に修正する。

図 14 左のように 2 つ正中面が一致したとき，連結面 との交線の向きを表す単位ベクトル $\mathbf{m}$ は, $\left(\mathbf{p}_{0}-\mathbf{p}_{1}\right) \times$ $\mathbf{n}_{1} /\left\|\left(\mathbf{p}_{0}-\mathbf{p}_{1}\right) \times \mathbf{n}_{1}\right\|$ で与えられる。連結点 $\mathbf{p}$ は交線上に $\mathbf{p}_{0}$ を中心に次の 2 つの候補が得られる.

$$
\mathbf{p}=\mathbf{p}_{0} \pm \sqrt{h_{1}^{2}-\left\|\mathbf{p}_{0}-\mathbf{p}_{1}\right\|^{2}} \mathbf{m}
$$

この 2 つの連結点候補のうち, 手首の位置から推測される 連結点の予想領域に含まれる方を連結点とする。図 15 に は, 直立姿勢の推定結果を示す。この姿勢は直立姿勢のう ちの前屈姿勢である.

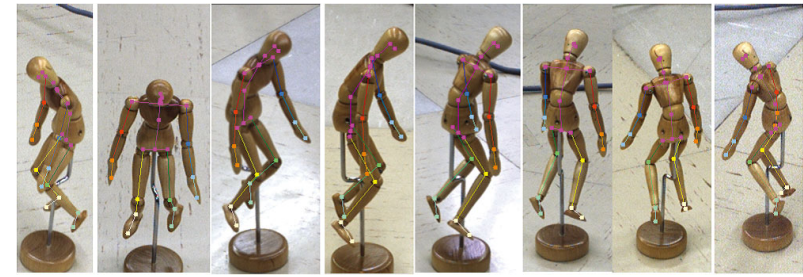

図 15 直立姿勢の推定結果
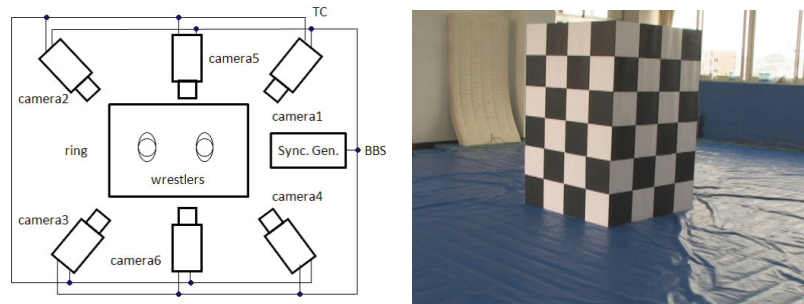

図 16 多視点カメラの配置（左）とカメラ較正用箱（右）

\section{5. 姿勢推定実験}

レスリングをしているレスラーの姿勢推定を行った。肩 関節と股関節位置から胴体の姿勢を推定する方法は既に述 ベた。ここでは，前処理として，肩関節と股関節位置を与 える方法を示す。また，後処理として，キーフレームで推 定された身体姿勢から身体動作の追跡法を示す。さらに, 動作の測定結果を 3D アニメーションで示す。なお，レス ラーの身体サイズは予め測定しておき，実測に基づく骨格 モデルを用意しておく.

\section{1 多視点カメラシステムとカメラ較正}

レスリングの練習試合を対象とした．矩形のリングの四 隅に 1 台ずつ，リングの辺の一つに 1 台，向かい合う辺に 1 台, 合計 6 台のビデオカメラ (CANON, XH-G1) で撮影し た。カメラの配置を図 16 左に示す。各カメラには外部同 期信号が有線で供給されている。また，1つのカメラをマス タカメラとし, このカメラの SMTPEタイムコード (TC) を有線で残りのカメラに供給している.

ビデオカメラの映像は DV テープに記録される.ビデオ 編集機 (トムソン・カノープス, REXCEED model 3100) で，DVテープから TC を読み取りながらハードディスク に画像を移す。同時刻に撮影された 6 枚 1 組の多視点画像 の時系列が得られる。

カメラ較正はTsai の方法 ${ }^{13)}$ を使用した。図 16 右のチェッ カ模様の箱がカメラ校正用の参照物体である。この物体に 参照座標系を置き，カメラ投影中心の位置座標と座標系原 点からの距離及び画幅を 1 としたときの焦点距離が表 1 に 示されている，画像解像度は $640 \times 480$ 画素であり，1 画 素幅あたりの座標系原点付近の測定精度が最後の列に示さ れている．単位は焦点距離を除きすべて $m m$ である．測定 領域 (座標系原点付近) の測定精度は $6 \mathrm{~mm}$ 程度である。力 メラは多方向に配置されているので，1画素あたりの測定 精度は，ほぼ $1 \mathrm{~mm}$ の球体内に収まっている。 
表 1 レスラー用カメラの 1 画素あたりの測定精度

\begin{tabular}{c|r|r|c|r|r|r}
\hline Camera & \multicolumn{1}{c|}{$\mathrm{x}$} & $\mathrm{y}$ & $\mathrm{z}$ & Distance & Focal length & Error \\
\hline$\# 1$ & -3093.30 & -3012.33 & 1192.94 & 4479.48 & 1.5221 & 4.60 \\
\hline$\# 2$ & 4942.13 & -3147.09 & 1184.10 & 5977.54 & 1.6120 & 5.79 \\
\hline$\# 3$ & 4616.80 & 4539.20 & 1179.00 & 6580.97 & 1.4778 & 6.96 \\
\hline$\# 4$ & -3246.08 & 4337.17 & 1190.50 & 5546.65 & 1.4664 & 5.91 \\
\hline$\# 5$ & 368.29 & -3694.01 & 1383.16 & 3961.63 & 1.1352 & 5.45 \\
\hline$\# 6$ & 158.30 & 4137.72 & 1116.89 & 4288.73 & 0.9737 & 6.88 \\
\hline
\end{tabular}

表 2 モデル人形用カメラの 1 画素あたりの測定精度

\begin{tabular}{c|r|r|r|r|r|r}
\hline Camera & \multicolumn{1}{|c|}{$\mathrm{x}$} & $\mathrm{y}$ & $\mathrm{z}$ & Distance & Focal length & Error \\
\hline$\# 1$ & -656.87 & 503.59 & 708.78 & 1089.70 & 2.2876 & 0.74 \\
\hline$\# 2$ & 153.89 & 903.83 & 715.22 & 1162.81 & 2.3745 & 0.77 \\
\hline$\# 3$ & 824.93 & 559.39 & 538.51 & 1132.88 & 2.2099 & 0.80 \\
\hline$\# 4$ & 1048.17 & 166.45 & 545.60 & 1193.33 & 2.4968 & 0.75 \\
\hline$\# 5$ & 881.00 & -361.08 & 543.69 & 1096.42 & 2.2750 & 0.75 \\
\hline$\# 6$ & 494.27 & -780.53 & 543.16 & 1071.71 & 2.1552 & 0.78 \\
\hline$\# 7$ & -354.21 & -853.91 & 770.39 & 1203.39 & 2.4430 & 0.77 \\
\hline$\# 8$ & -870.34 & -357.90 & 782.99 & 1224.20 & 2.4894 & 0.77 \\
\hline
\end{tabular}

モデル人形は高さが $23 \mathrm{~cm}$ であるので, 8 台の小型ビデオ カメラシステム (IEEE 1394 Flea2 CCD Camera, Point Gray) を使用した。画像解像度は同じく $640 \times 480$ 画素で ある。カメラ較正結果をレスリングで使用したカメラと同 様に表 2 に示す。この場合，1画素あたりの測定精度はほ ほ $0.77 \mathrm{~mm}$ の球体内に収まっている。

\section{2 肩関節と股関節位置の推定}

ターレンスモデル人形では，肩関節や股関節は剥き出し になっているため，その位置を画像からマウスポインティ ングにより直接与えることもできる。しかし，実際の身体 では，肩関節や股関節の位置と思われる領域は広く，関節 位置は指定する人によってブレを生じる，そこで，腕部・ 脚部領域と, 予め実測しておいた部位の長さから肩と股関 節の位置を推定する方法を示しておく。

身体各部位の主軸を体軸とよび，体軸の投影面上への射 影を中心軸とよぶ。体軸は直接観測することはできないが, 腕や脚などの部位は円筒で近似することができるので，中 心軸は部位の投影像から容易に得られる。

複数の異なる視点から撮影された画像に対し，各部位の 中心軸を与える。中心軸は部位領域の真中を通るように手 作業で与える。図 1 に，6つのカメラから撮影された画面 上の中心軸を示す。中心軸の両端点を指定するが，端点は 関節位置でなくてもよい. この中心軸情報から，四肢の位 置・姿勢を決定する。なお，頭部については頭部中心と眉 間の位置を指定する。

\section{(1) 体軸の方向}

体軸はカメラ視点と中心軸を含む平面に載っているので, 複数の視点で観測された中心軸から平面の交線として体軸 が得られる。四肢の一つの部位を一つの視点から観測した とき，その体軸を通る平面方程式を $\mathbf{a}_{i}^{\top} \mathbf{x}=f_{i}$ とする。 た だし， $\mathbf{a}_{i}$ は面の単位法線ベクトル， $\mathbf{x}$ はシーン空間中の座 標值, $f_{i}$ は原点から平面までの有向距離, $i$ は視点番号と する。平面の具体的な計算法を付録 $\mathrm{A}$ に示す。体軸の向き

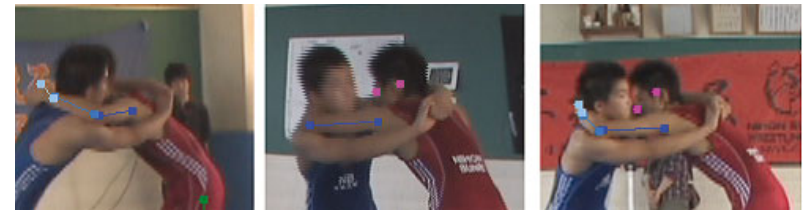

図 17 三つの視点から見た上腕の中心軸が同一のエピポーラ 線上に載っている

を単位ベクトル $\mathbf{u}$ とすれば，このベクトルは平面に含まれ るので, $\mathbf{u}^{\top} \mathbf{a}_{i}=0$ である。一つの体軸を通る平面が多数 存在するとき，体軸の向きは

$$
J=\sum_{i}\left(\mathbf{u}^{\top} \mathbf{a}_{i}\right)^{2}=\mathbf{u}^{\top} A \mathbf{u}
$$

を最小とする $\mathbf{u}$ を求める問題となる。 ここで, $A=\sum_{i} \mathbf{a}_{i} \mathbf{a}_{i}^{\top}$ とする。このとき，体軸の向きは行列 $A$ の最小固有值に対 する単位固有べクトルとして与えられる。

（2）时・膝関節位置

肘は上腕と下腕の体軸の交点である。したがって, 肘は 上腕や下腕の体軸を通る平面に載っている。この平面の交 点から肘の位置が得られる．平面の数が多数あれば，肘の 位置は各平面までの距離の総和が最小となる点として求め る。距離の総和は,

$$
J=\frac{1}{2} \sum_{i}\left\|\mathbf{a}_{i}^{\top} \mathbf{x}-f_{i}\right\|^{2}
$$

で与える。

$J$ を最小にする解は, $\frac{\partial J}{\partial \mathbf{x}}=\mathbf{0}$, すなわち

$$
A \mathbf{x}=\sum_{i} \mathbf{a}_{i} f_{i}
$$

を $\mathrm{x}$ について解けば肘の位置が得られる。

膝の位置も同様にして求めることができる.

（3）肩関節・股関節位置

肘が曲がっているときは, 線形連立方程式 (29) が 1 次独 立となり，肘の位置は一意に決定される。肘を始点に上腕 の体軸方向に上腕の長さほど進み肩位置を得る。

しかし，上腕の体軸が一意に決まらないこともある。図 17 の 3 枚のステレオ画像では，左上腕の中心軸（青色）は ほぼ水平で，同一のエピポーラ面に載っている。このとき 視点と中心軸を含むすべての平面は一致しているので，体 軸の向きを決定することはできない。そこで，精度は良く ないが，体軸の向きを肩関節の予想位置から求めることに する．上腕の中心軸を 2 点のポインティングで指定すると き， 1 点を肩位置とする. 付録 $\mathrm{B}$ の方法で肩関節の 3 次元 予想位置を求める．肘からこの予想位置の方向に上腕の長 さほど進んだ位置を肩関節の位置とする。

肘が真直ぐに伸びているときは, 線形連立方程式 (29) が 一次従属となり，肘の位置を一意に決定することができな い。このような場合には, 肘の位置を求めることはあきら め，手首の位置をポインティングで指定しておく，手首や 
表 3 関節位置の精度：提案法と従来法の比較

\begin{tabular}{l|c|c|c|r}
\hline Methods & $\mathrm{x}$ & $\mathrm{y}$ & $\mathrm{z}$ & Volume \\
\hline Existing & 9.42 & 15.2 & 25.58 & 15,342 \\
\hline Proposed & 1.03 & 2.77 & 13.41 & 160 \\
\hline
\end{tabular}

足首は括れているので，肘や肩の位置よりは特定し易いと 考えられる. 付録 B の方法で手首の 3 次元位置を求める. 肘が真直ぐに伸びているので，下腕と上腕を 1 本の腕と 見なして体軸方向を求める。体軸方向が一意に決まってい れば，手首位置から体軸方向に下腕の長さほど進んだ位置 を肘とし，さらに上腕の長さほど進んだ位置を肩関節位置 とする．体軸の向きを一意に決定することができなければ, 手首位置と肩関節の予想位置から体軸方向を求め，下腕 · 上腕の長さを使って肩関節位置を推定する。

股関節の位置も同様にして求めることができる。なお, 頭部と眉間の 3 次元位置も付録 B の方法で得ておく.

（4）既存手法との比較

関節位置からモデルを照合する従来法 ${ }^{11)}$ と本手法を比較 する．従来法 ${ }^{11)}$ は単眼視を仮定しているが，多視点画像か ら得られた 3 次元関節位置へのモデル照合とする。従来法 では関節位置を直接指定するのに比べ，提案手法は中心軸 から推定している。前節で示したモデル人形は関節位置を 直接指定することができるため，どちらの手法でも大差な いと考えられる。実際，前節のモデル人形に重ねられた骨 格に示されるように，提案手法でもほぼ正確に関節位置が 推定されていることが見て取れる。しかし，レスラーの例 では，関節位置の直接指定は指定者によりブレがあると考 えられる。股関節位置を直接指定した場合と, 中心軸から 推定した場合の関節位置の標準偏差を表 3 に示す．単位は 標準偏差は $m m$, 体積は $m^{3}$ である. 3 次元座標值の標 準偏差，及び標準偏差を軸長とした楕円体の体積を求めた ところ，本手法は従来法に比べてブレが少ないことが示さ れた。

モデルの照合の結果は，胴体部位で精度が異なる。従来 法では胴体が一つの剛体であるため，首と股関節を結ぶ直 線が部位の体軸となる。これに対し，提案法は二つの剛体 で同体部を表している。モデル人形の例で得られた部位の 体軸は，提案法の優位性を示している。図 8,9,13,15のモ デル人形に重ねられた連結点位置は，どの視点から見ても 胸部と腰部をつなく球体関節部のほぼ心に位置しており, 連結点が正確に得られていることが示されている。

（5）提案手法の限界

本論文で用いた多関節モデルは身体形状の近似モデルで ある。したがって，身体との靟離が大きくなればモデル照 合の精度が悪くなる。ここでは，計量的な乘離と位相的な 乘離が，それぞれモデル照合にどの程度の影響を及ぼすか 議論する。

まず，計量的な乘離について，腰部と胸部の高さを $5 \%$ 及 び $10 \%$ 増加させた場合の連結点の位置を図 18(a), (b)に

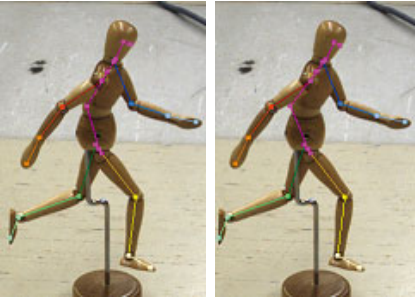

(a)

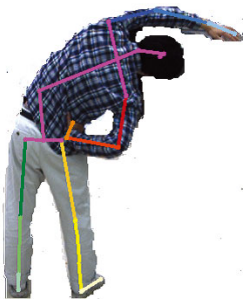

(c)
図 18 不適切な条件下での骨格推定, 胴体の高さを (a) $5 \%$, （b) $10 \%$ 伸ばした場合，(c) 身体を真横に曲げた場合

それぞれ示す。眓 8 左と比べると，連結点位置はモデル人 形の後部にずれ，部位のサイズに敏感であることがわかる.

一方，位相的な乘離について，本論文のモデルは肩部位 がなく，上腕は胴体に直接つながっている。実際の身体で は，肩部位があることにより肩関節は胸部に対して動いて いる。そのため，腕を上に上げたとき，身体の肩関節も上に 向かって上がるので，提案法はうまく働かない。実際，図 18 (c) のように，身体を真横に傾けたとき，本手法では連 結点は身体の外に向かって位置がずれた。

\section{3 トラッキング}

身体の姿勢が与えられると，姿勢の変位は画像間差分を 使って容易に得られる ${ }^{16)}$. 先頭フレームで身体の姿勢が与 えられると, 得られた姿勢の変位をフレーム順に累積する ことにより身体の 3 次元追跡が行える。しかしながら，こ の累積は誤差も累積されるために，長時間の追跡ではドリ フトが生じる。そこで，最終フレームでも姿勢を与え，累 積より計算された姿勢が最終フレームでの姿勢と一致する ように姿勢の変位を修正する ${ }^{17)}$. 途中のフレームでも正確 な追跡を行うためには，先頭と最終フレーム以外にも，い くつかの中間フレームをキーフレームとし，キーフレーム で姿勢を与え，キーフレーム間で追跡を行う。

\section{4 身体の動作推定}

肩関節と股関節位置から実際の身体の姿勢を推定し，さ らに動作の追跡結果を示す。

式 (9) で計算される $|\sin \theta|$ 及び，式 (10) で計算される $\cos \phi$ の大きさによって姿勢を念転姿勢と念転以外の特異姿 勢（横斜姿勢，直立姿勢）に分類し，それぞれの計算法で 姿勢を得る。すなわち， $t_{\theta}, t_{\phi}$ を闇值として，

(a) $|\sin \theta|>t_{\theta}, \quad|\cos \phi|>t_{\phi}$ のとき，捻転姿勢，

(b) $|\sin \theta|>t_{\theta}, \quad|\cos \phi| \leqq t_{\phi}$ のとき，横斜姿勢，

(c) $|\sin \theta| \leqq t_{\theta}$ のとき，直立姿勢，

として，連結点を求める。本実験では，閾值 $t_{\theta}$ をちえる $\theta$ を $\pm 1^{\circ} ， t_{\phi}$ を与える $\phi$ を $90^{\circ} \pm 1^{\circ}$ とした。 この閾值設定 では特異姿勢に分類されることはまずない。図 13,15 の実 験では， $t_{\theta}$ を与える $\theta$ を $\pm 10^{\circ}, t_{\phi}$ を与える $\phi$ を $90^{\circ} \pm 10^{\circ}$ として特異姿勢を作り出して計算方法の正しさを確認した. 練習試合中の 2 人のレスラーの動作を追跡した．試合着 のシングレットは裸の身体に密着しているため，レスラー 一人だけなら，画像から胴体の体軸を求めるのはさほど難 


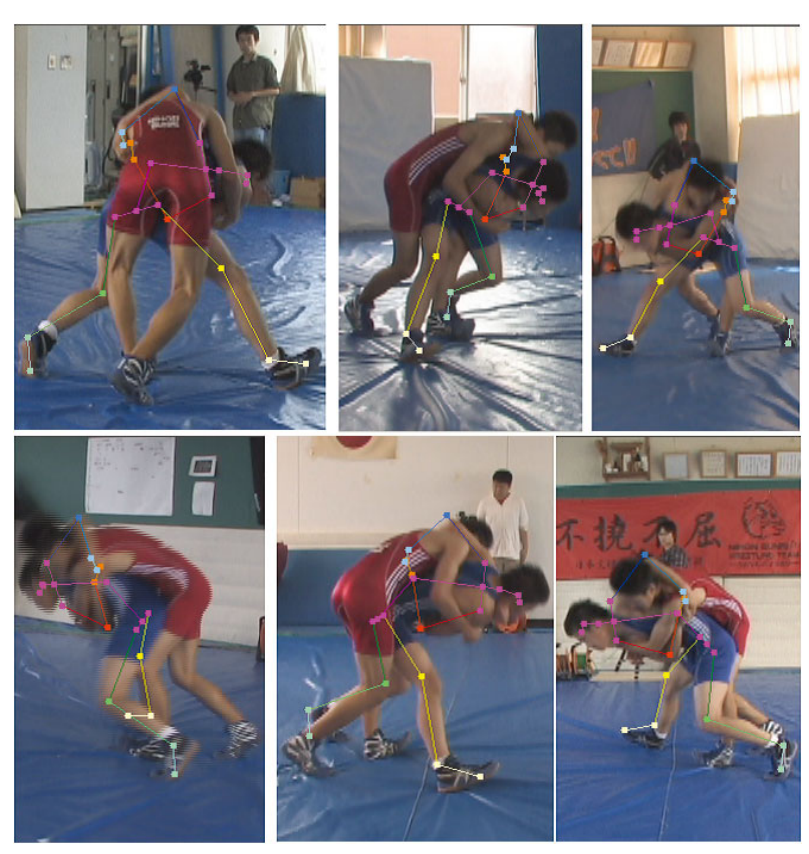

図 19 首投げの瞬間の姿勢推定

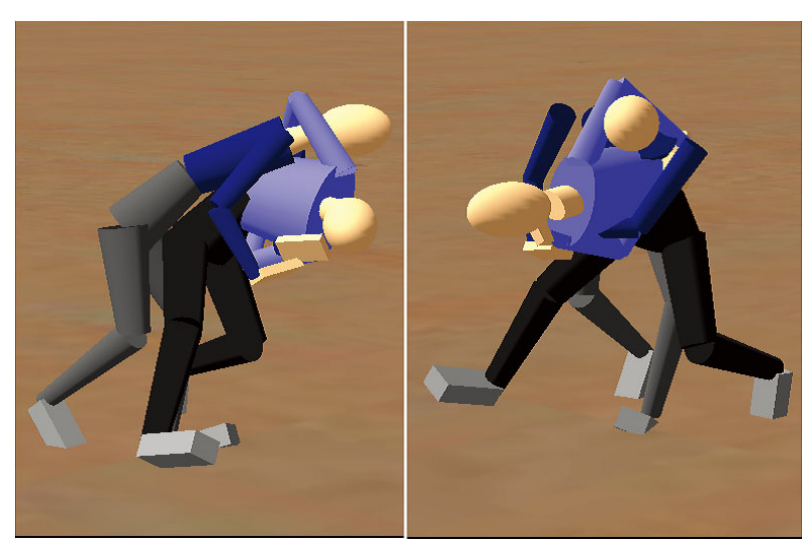

図 20 首投げの瞬間の CG による再現

しくはない。しかし，試合ではレスラーが互いに絡み合い 胴体が相手の体に隠されることが多いため, 提案する姿勢 の推定手法が有効である.

図 1 で指定された中心軸から推定された全身の姿勢を体 軸で図 19 に示す。胴体と頭部の体軸がピンク色で示され ている。同様にもう一人のレスラーの体軸も推定し, 両者 をCGにより復元した結果を図 20 に示す。首投げをして いる瞬間が良くわかる.なお，この CG 画像では黒い夕イ ツのキャラクタが青いシングレットのレスラーであり，グ レーのタイツのキャラクタが赤いシングレットのレスラー である。

首投げ技をかけているレスラーと技をかけられているレ スラー, 二人の動作追跡を行った. 73 フレームの動画であ るが，先頭と最終フレーム以外にも 18 フレームものキー フレームで姿勢を推定した。 これは, 互いの身体が複雑に 絡み動作が早いところでは，2?3 フレーム連続してキーフ レームを挿入せざるを得なかったためである，追跡結果の ビデオ映像を Web 上 ${ }^{18)}$ に公開しておく。このビデオで体
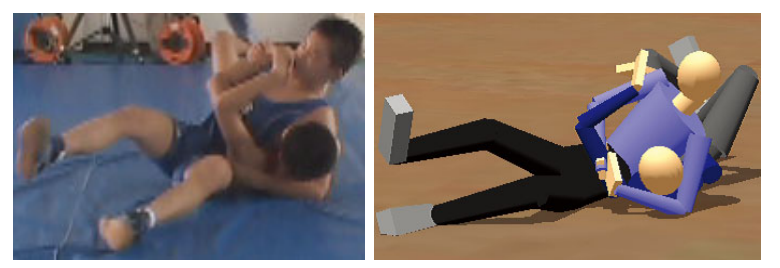

図 21 腕部位の隠れ (左) と不充分な復元 (右)

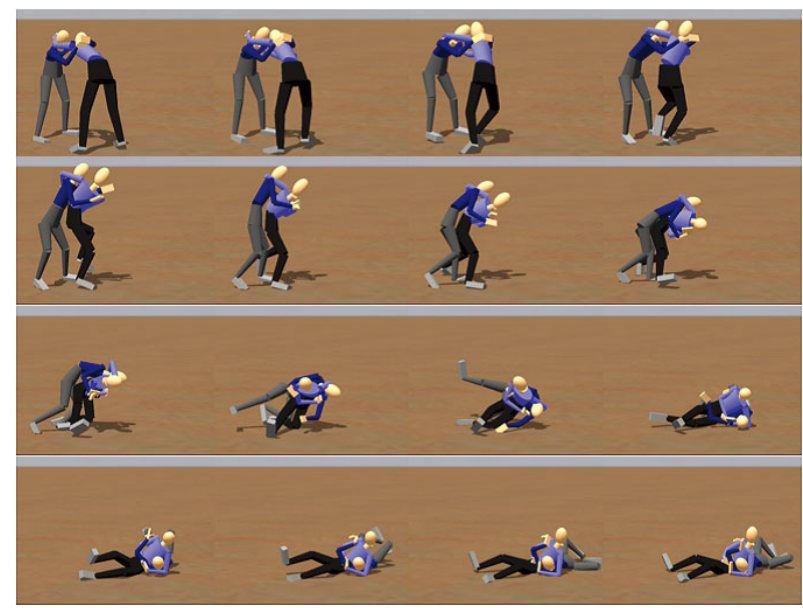

図 22 レスリングのアニメーション

軸が赤いときはキーフレームで, カラフルに色付けされて いるときは中間フレームである. 首投げのアニメーション から 5 コマずつ抜き出した画像を図 22 に示す。このアニ メーションも Web 上 ${ }^{18)}$ に公開しておく.

20 キーフレームのすべてにおいて, 少なくとも 2 視点か ら四肢の中心軸が観測され, 肩関節・股関節の位置を決定 することができた。ただし，隠れにより部位の一部しか見 えていない場合でも推測により中心軸を指定している。例 えば，図 21 左に示される青シングレットを着たレスラー の右下腕は，相手の左上腕に重なり大部分が見えない. 右 下腕の向きは左上腕と平行であると仮定し中心軸を与えた. しかし, 図 21 右の復元結果では, 右下腕が相手の左上腕を 貫通しており測定精度が充分ではなかった。

最後に，作業にかかった時間を示しておく．1キーフレー 厶 6 画像上で四肢の中心軸を指定するのに約 6 分必要とす る.キーフレームの総数は 20 フレームであるので, 約 72 分かかった。また，全 73 フレームの追跡は，ドリフトの 修正を含むため約 2 分かかった。使用した計算機の CPU は Intel Core i7 860, 2.8GHz 3.49GB RAM で, OS は Windous XPであった。やはり, 手動による中心軸指定に ほとんどの時間が費やされている。

\section{6. むす び}

レスリング競技を対象に，互いに絡み合った身体の姿勢 と動作の測定法を提案した。四肢の関節位置がわかれば, 胴体の姿勢を推定することができるため, 胴体が大きめの 衣服や携帯物などで隠されていても，四肢が観測できれば 胴体の姿勢が推定可能である. 今回, 腕や脚の中心軸は手 
動で与えたが，レスリング選手の四肢の抽出は肌色抽出な どの色処理で可能である。今後は，絡み合った身体の自動 認識を行いたい.

謝辞 レスリング映像の撮影にご協力いただいた，日本 文理高校レスリング部員の皆様に感謝する。なお，本研究 は JSPS 科研費 $(21500161 ， 26330190)$ の助成を受けたも のである。ここに謝意を表す。

\section{〔文献〕}

1) E. de Aguiar, C.Stoll, C.Theobalt, N.Ahmed, H.-P.Seidel S.Thrun, "Performance capture from sparse multi-view video", ACM Transactions on Graphics, 27, 3, Article 98 (2008)

2) C. Barron, I. A. Kakadiaris, "Estimating anthropometry and pose from a single uncalibrated image", Computer Vision and Image Understanding. 81, pp.269-284 (2001)

3) C. Bregler, J. Malik, "Twist based acquisition and tracking of animal and human kinematics", International Journal of Computer Vision, 56, 3, pp.179-194 (2004)

4) I. Cohen, M. W. Lee, "3D body reconstruction for immersive interaction", 2nd International Workshop on Articulated Motion and Deformable Objects (2002)

5) D.M.Gavrila and L.S.Davis, "3-D model-based tracking of humans in action: A multi-view approach", IEEE Conf. Computer Vision and Pattern Recognition, pp.73-80 (1996)

6) M. W. Lee, I. Cohen, S. K. Jung, "Particle filter with analytical inference for human body tracking", Workshop on Motion and Video Computing, pp.159-168 (2002)

7) G. Mori, X. Ren, A. A. Efros, J. Malik, "Recovering human body configurations: Combining segmentation and recognition", IEEE Conf. Computer Vision and Pattern Recognition, 2, pp.326-333 (2004)

8) R. Navaratnam, A. Thayananthan, P. H. Torr, R. Cipolla, "Hierarchical part-based human body pose estimation", British Machine Vision Conference (2005)

9) D. Ramanan, D. A. Forsyth, A. Zisserman, "Tracking people by learning their appearance", IEEE Trans. Pattern Analysis and Machine Intelligence, 29, 1, pp.65-81 (2007)

10) J. Shotton, T. Sharp, A. Kipman, A. Fitzgibbon, M. Finocchio, A. Blake, M. Cook,R. Moore, "Real-time human pose recognition in parts from single depth images",Communications of the ACM, 56, 1, pp.116-124 (2013)

11) C. J. Taylor, "Reconstruction of articulated objects from point correspondences in a single uncalibrated image", Computer Vision and Image Understanding, 80, 3, pp.349-363 (2000)

12) Deepak Tolani, Ambarish Goswani, and Norman I. Badler, "Realtime inverse kinematics techniques for anthropomorphic limbs", Graphical Models, 62, pp.353-388 (2000)

13) R.Y.Tsai, "A versatile camera calibration technique for highaccuracy 3D machine vision metrology using off-the-shelf TV cameras and lenses", IEEE Journal of Robotics and Automation, RA.3, 4,pp.323-344 (1987)

14) X. K. Wei, J. Chai, "Intuitive interactive human-character posing with millions of example poses", IEEE Computer Graphics and Applications, 31, 4, pp.78-88 (2011)

15）山根克，中村仁彦，“ヒューマンフィギュアの全身運動生成のための共 応構造化インターフェース”，日本ロボット学会誌， 20, 3, pp.335-343 (2002)

16) M.Yamamoto, A.Sato, S.Kawada, T.Kondo and Y.Osaki, "Incremental tracking of human actions from multiple views", IEEE Conf. Computer Vision and Pattern Recognition, pp.2-7 (1998)

17）山本正信，“ドリフト修正機能を有する動画像からの身体動作推定法”, 信学論, J88-D-II, 7, pp.1153-1165 (2005)

18) http://www.vision.ie.niigata-u.ac.jp/motion-capture-wrestling.html

〈付録〉

\section{A．視点と体軸を通る平面}

3 次元座標值を $\mathrm{x}$ と表す．体軸の投影である中心軸上の 2 点をべクトル $\mathbf{p}_{j}, \mathbf{p}_{k}$, 視点を $\mathbf{p}_{i}$ とする。これらのベクト ルはシーン座標系で表されているものとする。このとき，
これらの 3 点を含む平面方程式は，

$$
\left|\begin{array}{cccc}
1 & 1 & 1 & 1 \\
\mathbf{x} & \mathbf{p}_{i} & \mathbf{p}_{j} & \mathbf{p}_{k}
\end{array}\right|=0
$$

で与えられる。この方程式は平面方程式の標準形

$$
\mathbf{a}^{\top} \mathbf{x}=f
$$

と表すこともできる。ただし，aは単位法線べクトル， $f$ は 原点から平面への有向距離である。

\section{B. 多視点カメラからの 3 次元座標值}

投影面上で 3 次元点の位置が観測されたとき，視点から 3 次元点への方向を示す単位ベクトルを $\mathbf{b}_{i}$, 視点位置を $\mathbf{c}_{i}$ としたとき，視線を $t_{i}$ をパラメータとして，

$$
\mathbf{x}=\mathbf{b}_{i} t_{i}+\mathbf{c}_{i}
$$

と表す. 3 次元点の位置は複数の視点からの視線の交点と して得られるが，視線が 1 点で交わることはまずない。そ こで，視線への距離の総和が最も小さな点として 3 次元点 の位置を求める。

3 次元点の位置を $\mathrm{x}_{0}$ として, 距離の総和を

$$
J=\frac{1}{2} \sum_{i}\left\|\mathbf{n}_{i} t_{i}+\mathbf{c}_{i}-\mathbf{x}_{0}\right\|^{2}
$$

とし,

$$
\frac{\partial J}{\partial t_{i}}=0, \frac{\partial J}{\partial \mathbf{x}_{0}}=\mathbf{0}
$$

から 3 次元点の位置 $\mathbf{x}_{0}$ を得る.

評価式 (付·2) は,

$$
\begin{aligned}
J= & \frac{1}{2} \sum \mathbf{b}_{i}^{\top} \mathbf{b}_{i} t_{i}^{2}+\sum \mathbf{b}_{i}^{\top}\left(\mathbf{c}_{i}-\mathbf{x}_{0}\right) t_{i} \\
& +\frac{1}{2} \sum\left(\mathbf{c}_{i}-\mathbf{x}_{0}\right)^{\top}\left(\mathbf{c}_{i}-\mathbf{x}_{0}\right) \\
= & \frac{1}{2} \sum\left(\mathbf{b}_{i} t_{i}+\mathbf{c}_{i}\right)^{\top}\left(\mathbf{b}_{i} t_{i}+\mathbf{c}_{i}\right) \\
& -\sum\left(\mathbf{b}_{i} t_{i}+\mathbf{c}_{i}\right)^{\top} \mathbf{x}_{0}+\frac{1}{2} \sum \mathbf{x}_{0}^{\top} \mathbf{x}_{0}
\end{aligned}
$$

と展開できるので，式 (付·3) を $t_{i}$ で微分し 0 と置けば,

$$
\mathbf{b}_{i}^{\top} \mathbf{b}_{i} t_{i}+\mathbf{b}_{i}^{\top}\left(\mathbf{c}_{i}-\mathbf{x}_{0}\right)=0
$$

を得，式 (付·4)を $\mathrm{x}_{0}$ で微分し 0 と置けば,

$$
-\sum\left(\mathbf{b}_{i} t_{i}+\mathbf{c}_{i}\right)+N \mathbf{x}_{0}=\mathbf{0}
$$

を得る。ここで，Nは視点の数である。

この結果から $t_{i}, \mathbf{x}_{0}$ を未知数とする次の線形連立方程式 が得られる。

$$
\left(\begin{array}{ccccc}
\mathbf{b}_{1}^{\top} \mathbf{b}_{1} & & & & -\mathbf{b}_{1}^{\top} \\
& \mathbf{b}_{2}^{\top} \mathbf{b}_{2} & & & -\mathbf{b}_{2}^{\top} \\
& & \ddots & & \vdots \\
& & & \mathbf{b}_{N}^{\top} \mathbf{b}_{N} & -\mathbf{b}_{N}^{\top} \\
-\mathbf{b}_{1} & -\mathbf{b}_{2} & \ldots & -\mathbf{b}_{N} & N I_{3 \times 3}
\end{array}\right)
$$




$$
\times\left(\begin{array}{c}
t_{1} \\
t_{2} \\
\vdots \\
t_{N} \\
\mathbf{x}_{0}
\end{array}\right)=\left(\begin{array}{c}
-\mathbf{b}_{1}^{\top} \mathbf{c}_{1} \\
-\mathbf{b}_{2}^{\top} \mathbf{c}_{2} \\
\vdots \\
-\mathbf{b}_{N}^{\top} \mathbf{c}_{N} \\
\sum \mathbf{c}_{i}
\end{array}\right)
$$

ここで, $I_{3 \times 3}$ は 3 次の単位行列である。 この方程式を解く ことにより, 3 次元点 $\mathbf{x}_{0}$ が得られる.

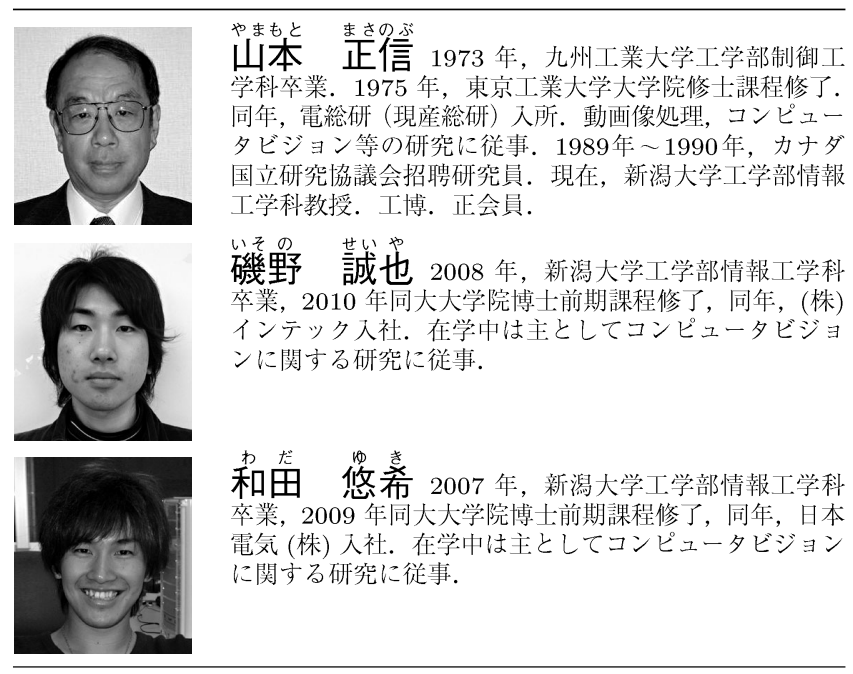

